\title{
The assessment of the cardioprotective effectiveness of levosimendan on patients with impaired left ventricle functions and less than $\% 40$ of ejection fraction who will receive coronary artery bypass graft operation
}

\author{
Sol ventrikül fonksiyonları bozulmuş, ejeksiyon fraksiyonu \%40'in altında olan, koroner \\ arter by-pass greft operasyonu yapilacak hastalara verilen levosimendan tedavisinin, \\ kardiyoprotektif etkinliğinin postoperatif olarak değerlendirilmesi
}

\author{
(D) Merih Özbayburtlu' ${ }^{1}$, $\odot$ Yıldırım Gültekin², $\odot$ Hüseyin Gemalmaz ${ }^{3}$ \\ ${ }^{1}$ Özel Eskișehir Acıbadem Hospital, Department of Cardiovascular Surgery, Eskişehir, Turkey \\ ${ }^{2}$ Kırıkkale University, School of Medicine, Department of Cardiovascular Surgery, Kırıkkale, Turkey \\ ${ }^{3}$ Özel Bahçelievler Memorial Hospital, Department of Cardiovascular Surgery, İstanbul Turkey
}

Cite this article as/Bu makaleye atıf için: Özbayburtlu M, Gültekin Y, Gemalmaz H. The Assessment of the cardioprotective effectiveness of levosimendan on patients with impaired left ventricle functions and less than \%40 of ejection fraction who will receive coronary artery bypass graft operation. J Health Sci Med 2020; 3(4): 460-465.

\begin{abstract}
Aim: The purpose of this study is to demonstrate the postoperative cardioprotective efficacy of preoperative levosimendan treatment in patients with impaired left ventricular function undergoing coronary by-pass surgery.

Material and Method: This study was performed prospectively between November 2008 and September 2009 in Eskişehir Osmangazi Univercity Department of Cardiovascular Surgery. Twenty patients with coronary artery disease (CAD) between the ages of 48-78 and ejection fraction (EF) below $40 \%$ were included in the study. levosimendan was given to the first group preoperatively(experimental group). Group 2 was the control group. Coronary artery bypass graft (CABG) surgery was performed in all of them. One group received additional levosimendan infusion, preoperatively. Age, comorbidity, cardiopulmonary by-pass (CPB) time, cross clamp (CC) time, patient vessel number, anastomosis number, extubation times, intensive care stay and hospital stay were recorded. Preoperative, postoperative 1st day and postoperative 7 th day nt-proBNP values and preoperative and postoperative 15th day ejection fraction (EF) values with echocardiography (ECHO) were measured. The cardioprotective efficacy of the drug was evaluated by comparing the data of the control group and the experimental group.

Results: No statistically significant difference was found between the two groups in terms of CPB time, CC time, age, comorbidity, number of sick vessels, number of anastomosis, extubation time, length of stay in intensive care and hospital stay. $(\mathrm{p}>0.05)$. There was no significant difference between the groups in preoperative $\mathrm{EF}$ values ( $p>0.05$ ). The mean values of EF measurements on the postoperative 15 th day were calculated as $39 \%$ in the experimental group and $40 \%$ in the control group. The increase in $\mathrm{EF}$ values was greater in the experimental group. This increase was found to be more significant in the experimental group $(\mathrm{P}=0.008)$. There was a significant difference between the groups in preoperative and postoperative 1 st day $n$-tproBNP values $(\mathrm{p}<0.05)$. A significant increase was observed in nt-proBNP values in the groups until the 7 th postoperative day. $(\mathrm{p}<0.001)$. Although this increase was statistically significant in both groups, it was observed that the increase in the control group was higher. After the nt-proBNP measurements on the postoperative 7 th day, there was no significant difference between the two groups ( $p>0.05$ ). Conclusion: As a result of this study, it was determined that levosimendan has a positive effect on myocardial protection and contractility in patients with low EF in CABG surgery.

Keywords: Levosimendan, coroner by-pass surgery, left ventricle dyusfunction
\end{abstract}

\section{ÖZ}

Amaç: Bu çalışmanın amacı koroner by-pass ameliyatı yapılacak, sol ventrikül fonksiyonu bozulmuş hastalarda preoperatif levosimendan tedavisinin postoperatif kardiyoprotektif etkinliğini göstermektir.

Gereç ve Yöntem: Bu çalışma Kasım 2008- Eylül 2009 tarihleri arasında, Eskişehir Osmangazi Üniversitesi Tip Fakültesi Kalp ve Damar Cerrahisi Anabilim Dalında prospektif olarak gerceklestirildi. Calışmaya yașları 48-78 arasında, ejeksiyon fraksiyonu (EF) \%40'in altında koroner arter hastalığı (KAH) olan 20 hasta alınd. Hastalar iki gruba ayrild. 1. gruba preoperatif levosimendan verildi (deney grubu). 2. grup kontrol grubuydu. Hepsine koroner arter bypass greft (KABG) cerrahisi uygulandı. Yaş, komorbidite, kardiyopulmoner by-pass (KPB) zamanı, kros klemp (KK) zamanı, hasta damar sayısı, anastomoz sayısı, ekstübasyon süresi, yoğun bakımda ve hastanede kalıs süreleri kaydedildi. Preoperatif, postoperatif 1.gün ve postoperatif 7. gün nt-proBNP değerleri ve preoperatif ve postoperatif 15 . gün ejeksiyon fraksiyon $(\mathrm{EF})$ değerleri ekokardiyografiyle (EKO) ölçüldü. Kontrol grubu ve deney grubunun verileri karşılaştırılarak ilacın kardiyoprotektif etkinliği değerlendirildi.

Bulgular: İki grup arasında komorbidite, KPB zamanı, KK zamanı, yaş, hasta damar sayısı, anastomoz sayısı, ekstübasyon süresi, yoğun bakımda kalış süresi ve hastanede kalış süresi açısından istatistiksel olarak anlamlı farkllık saptanmadı. (P>0,05). Preoperatif ölçülen EF değerlerinde gruplar arasında anlamlı farklılık gözlenmedi $(P>0,05)$. Postoperatif 15. gündeki EF ölçümlerinin ortalama değerleri deney grubunda $\% 39$, kontrol grubunda $\% 40$ olarak hesaplandı. $\mathrm{EF}$ değerlerindeki artı̧ deney grubunda daha fazlaydı. Bu artışın deney grubunda daha anlamlı olduğu tespit edildi $(\mathrm{P}=0,008)$.

Gruplar arasında preoperatif ve postoperatif 1 . gün bakılan nt-proBNP değerleri arasında anlamlı farklılık vardı ( $<<0,05)$. Gruplarda nt-proBNP değerlerinde postoperatif 7. güne kadar anlamlı bir artı̧ gözlendi. $(\mathrm{p}<0,001)$. İstatistiksel olarak bu artış her iki grupta da anlamlı olmasına karșın kontrol grubundaki artışın daha fazla olduğu görüldü. Postoperatif 7. gün bakılan nt-proBNP ölçümleri sonrası 2 grup arasında anlamlı farklllık yoktu $(P>0,05)$.

Sonuç: Bu çalışma sonucunda KABG cerrahisinde düşük EF'li hastalarda levosimendaın myokardiyal koruma ve kontraktilite üzerine olumlu etkinliği olduğu saptandı.

Keywords: Levosimendan, koroner by-pass cerrahisi, sol ventrikül disfonksiyonu 


\section{INTRODUCTION}

CABG surgery is the main treatment for ischemic heart disease. Over the past 30 years, advances in surgical techniques have improved the quality of life. It has decreased the morbidity and mortality associated with $C A B G$ surgery and facilitated postoperative care (1). CABG still has high postoperative mortality and morbidity for patients with left ventricular dysfunction (LVD) compared to patients with normal left ventricular function (2). However, after long-term patient results and clinical follow-ups, it has been shown that coronary revascularization is superior to medical treatment for patients with low EF (3). CPB and cardioplegic arrest have disadvantages. These can be listed as systemic inflammatory response, myocardial damage, neurological damage, renal and pulmonary insufficiency.

Despite these disadvantages, the most important advantage of CPB is to reach the target vessels in the immobile, hollow heart and to perform complete revascularization by working in a bloodless environment (4) The improvement in left ventricular functions begins on the 1st and 3rd days. İt has been shown that significant improvement occurs at the end of 10-15 days. (5). Regardless of the cause of LVD, it has been reported that there is a significant improvement in left ventricular ejection EF after myocardial revascularization in 25$40 \%$ of CAD (6). Classical inotropic agents used in heart failure are $\alpha-\beta$ agonists (dobutamine, dopamine, epinephrine, norefinephrine) and phosphodiesterase III inhibitors (amrinone, milrinone). These drugs improve the cardiac output by increasing the stroke volume. They exert these effects by increasing the level of cyclic adenosine mono phosphate in cardiac myocytes (7). Levosimendan, which has been recently used in acute decompensated heart failure, increases the sensitivity of cardiac troponin-c to cytoplasmic calcium (8-6). The most important feature is that the intracellular calcium level does not increase during this inotropic effect. In this way, important side effects such as cardiac myocyte dysfunction and arrhythmia due to increased intracellular calcium during the effect of adrenergic inotropic agents are prevented. (9). Levosimendan causes arterial and venous dilatation by opening ATP-sensitive potassium channels in vascular smooth muscle cells (10). The contractile level effects caused by levosimendan provide a corrective effect on both preload and afterload of the heart. During this procedure, there is no increase in the oxygen consumption of the myocardium. Thanks to its vasodilation effect in coronary arteries, it also has anti-ischemic activity (11). Studies have shown that elevated brain natriuretic peptide (BNP) levels in patients with chronic heart failure reflect an increased risk of mortality. BNP is released from cardiomyocytes with its prepro hormone form, with increased left ventricular volume load and ventricular expansion. As a result of the studies, it was observed that plasma proBNP levels in left ventricular dysfunction correlated with the severity of symptoms and prognosis. Since BNP disappears from the blood in a very short time, measuring proBNP levels gives much more reliable results (12).

Our aim in this study is to investigate the cardioprotective efficacy of Levosimandan, which is given preoperatively to $\mathrm{CAD}$ with $\mathrm{LVD}$ undergoing CABG operation, by evaluating the nt-proBNP value and ECHO measurements.

\section{MATERIAL AND METHOD}

The study was carried out on 20 patients undergoing CABG at Eskişehir Osmangazi University Faculty of Medicine, Department of Cardiovascular Surgery, between November 2008 and September 2009. This study was approved by the university/local human research ethics committee and all procedures performed in studies involving human participants were conducted in accordance with the ethical standards of the institutional and/or national research committee, the 1964 Declaration of Helsinki and subsequent amendments or comparable ethical standards. All patients included in the study signed the Informed Consent Form. It was approved by Eskişehir Osmangazi University Faculty of Medicine Ethics Committee (Date: 10.11.2008, No: 2008/454).

A total of 20 patients ( 1 female and 19 male) with LVD $(\mathrm{EF}<40 \%)$ undergoing CABG were included in the study. It was divided into 2 groups of 10 people, namely the experimental group and the control group. Preoperative routine tests were performed for CABG. CABG operation had not been applied to any patient before. The same team did all the surgeries.

Levosimendan was started 24 hours before the operation. Solution for infusion $12.5 \mathrm{mg}$ in $500 \mathrm{ml}$ dextrose. It was prepared by adding levosimendan. The solution was given a $12 \mu \mathrm{gr} / \mathrm{kg}$ (microgram/kilogram) loading infusion in the first 10 minutes. There were no complications. In the following period, a maintenance infusion at a dose of $0.2 \mu \mathrm{gr} / \mathrm{kg} / \mathrm{min}$ was given.

Blood samples for Nt-proBNP level were taken $1^{\text {th }}$ day after the operation, 24 hours after the operation and on the 7 th day. Blood samples for Nt-proBNP level were taken 1 day after the operation, 24 hours after the operation and on the 7th day. Plasma NT-proBNP measurements were made in Elecsys 2010 using Roche Diagnostics'NTproBNP kit. In both groups, ventricular EF measurements were made by transthoracic echocardiography before the operation and on the 15th postoperative day. 
For anesthesia, 30 minutes before the operation, 0.05 $\mathrm{mg} / \mathrm{kg}$ morphine was administered intramuscularly for premedication. During induction, $0.3 \mathrm{mg} / \mathrm{kg}$ etomidate was given intravenously to all patients. Neuromuscular blocker $0.9 \mathrm{mg} / \mathrm{kg}$ rocuronium was administered. Sevoflurane anesthetic was started at 2-4\% MAC value. İntubation was performed. Patients were connected to a mechanical ventilator. Remifentanil infusion at 0.1-0.4 $\mu \mathrm{gr} / \mathrm{kg} / \mathrm{min}$ was started to the patients.

Median sternotomy was performed in operations. Internal mammarian artery and saphenous vein were prepared as grafts. Terumo ${ }^{\circ}$ Advanced Perfusion System 1 heart-lung machine was used in CPB. Standard cannulation was performed for CBP. Hot blood cardioplegia was given after distal anastomoses. Moderate (30-32 Co) hypothermia was applied. Diastolic cardiac arrest was performed. Cold blood cardioplegia was administered at 20-minute intervals for myocardial protection. Hot blood cardioplegia was administered after the distal anastomoses were made and before the cross-clamp was removed. Proximal anastomoses were performed with a side clamp. The patients were taken to the cardiovascular surgery intensive care unit. Patients who were hemodynamically and surgically stable were extubated.

Shapiro Wilk test was used to examine the distribution of variables. For normally distributed variables $t$ test, two way variance analysis and Holm Sidak multiple comparison test were used. Descriptive statistics were given as mean \pm standard error $(\mathrm{MEAN} \pm \mathrm{SD})$. Mann Whitney $\mathrm{U}$ test, Wilcoxon $\mathrm{T}$ test, Chi-square test and Spearman Correlation analysis were used for variables that were not normally distributed. Median 25\% and 75\% percentiles were given as descriptive statistics.

\section{RESULTS}

The ages of the patients participating in the study were between 48 and 78; The average age of the experimental group was $66.50 \pm 9.95$ and the average age of the control group was $59 \pm 7.28$. Biochemical analysis of nt-proBNP measurements measured on preoperative 1st day and postoperative 1st and 7th days from patients in both groups were Performed. At the same time, preoperative $\mathrm{EF}(\mathrm{EF} 0)$ and postoperative EF (EF15) of patients in both groups. measurements were made. The data are given in Table 1.

No statistically significant difference was found between the groups in terms of age, comorbitidity, CPB time, CC time, number of patient vessels, number of anastomosis, extubation times, length of stay in intensive care and hospital stay. No significant difference was observed between the groups in preoperative EF values ( $p>0.05)$. The data are shown in Table 2-3.

\begin{tabular}{|c|c|c|c|c|c|}
\hline & P0 & P1 & P7 & EF0 & EF15 \\
\hline $\mathrm{L} 1$ & 438 & 3009 & 3248 & 32 & 46 \\
\hline L2 & 1798 & 2854 & 2075 & 38 & 43 \\
\hline L3 & 3164 & 5798 & 10984 & 16 & 25 \\
\hline L4 & 2775 & 6820 & 5691 & 35 & 35 \\
\hline L5 & 1118 & 3677 & 3097 & 25 & 35 \\
\hline L6 & 2017 & 2674 & 6660 & 38 & 45 \\
\hline L7 & 1671 & 3696 & 4100 & 20 & 26 \\
\hline L8 & 793 & 3449 & 3113 & 35 & 51 \\
\hline L9 & 434 & 6361 & 3300 & 24 & 34 \\
\hline L10 & 1784 & 9618 & 9891 & 37 & 51 \\
\hline K1 & 1500 & 2099 & 3415 & 38 & 41 \\
\hline K2 & 2088 & 2882 & 2673 & 30 & 32 \\
\hline K3 & 492 & 4681 & 5718 & 32 & 35 \\
\hline K4 & 371 & 2415 & 6520 & 38 & 40 \\
\hline K5 & 1078 & 2517 & 3388 & 39 & 40 \\
\hline K6 & 53 & 1132 & 3501 & 39 & 44 \\
\hline K7 & 178 & 4047 & 7171 & 38 & 36 \\
\hline K8 & 415 & 1468 & 2779 & 39 & 44 \\
\hline K9 & 116 & 3077 & 4686 & 32 & 39 \\
\hline K10 & 1664 & 2355 & 3850 & 35 & 44 \\
\hline
\end{tabular}

\begin{tabular}{|lccccc|}
\hline \multicolumn{5}{|c}{ Table 2. Comorbidity in experimental group and control group } \\
\hline L (n:10) & $\mathbf{L}(\mathbf{\%})$ & $\mathbf{K}(\mathbf{n : 1 0})$ & $\mathbf{K}(\mathbf{\%})$ & $\mathbf{p}$ \\
\hline DM & 3 & 30 & 2 & 20 & $>0.05$ \\
HT & 4 & 40 & 3 & 30 & $>0.05$ \\
COPD & 3 & 30 & 2 & 20 & $>0.05$ \\
PAH & 1 & 10 & 2 & 20 & $>0.05$ \\
RD & 2 & 20 & 1 & 10 & $>0.05$ \\
HL & 4 & 40 & 3 & 30 & $>0.05$
\end{tabular}

DM: Diabetes mellutus, HT: Hypertension COPD: Chronic obstructive pulmonary disease, PAD: Peripheral artery disease, RD: Renal dysfunction, HL: Hyperlipidemia, L: Levosimendan given group; K: Control group.

\begin{tabular}{lccc|}
\hline \multicolumn{4}{|c}{ Table 3. Experimental group and control group perioperative data } \\
\hline & $\begin{array}{c}\text { Experimental } \\
\text { group mean } \pm \text { sd }\end{array}$ & $\begin{array}{c}\text { Control grup } \\
\text { mean } \pm \text { sd }\end{array}$ & p \\
\hline AGE & $66.5 \pm 9.95$ & $59 \pm 7.28$ & 0.071 \\
CBP (minute) & $112.6 \pm 41.02$ & $105.8 \pm 35.66$ & 0.697 \\
CCT & $66.4 \pm 28.14$ & $64.9 \pm 18.6$ & 0.890 \\
EF15 (\%) & $39.1 \pm 9.49$ & $39.5 \pm 4.11$ & 0.905 \\
- median (25\%-75\%) & median (25\%-75\%) & - \\
$\begin{array}{l}\text { Number of patient } \\
\text { veins }\end{array}$ & $4(4-4)$ & $4(3-4)$ & 0.435 \\
$\begin{array}{l}\text { Number of } \\
\text { Anastomosis }\end{array}$ & $3(3-4)$ & $3.5(3-4)$ & 0.630 \\
$\begin{array}{l}\text { Extubation time } \\
\text { (hours) }\end{array}$ & $4.5(4-5)$ & $5(5-5)$ & 0.251 \\
$\begin{array}{l}\text { Intensive care stay } \\
\text { (days) }\end{array}$ & $1.5(1-2)$ & $2(1-2)$ & 0.661 \\
$\begin{array}{l}\text { Hospital length } \\
\text { of stay (days) }\end{array}$ & $6.5(5-7)$ & $6.5(6-7)$ & 0.548 \\
\hline $\begin{array}{l}\text { KKT: Cross Clamp Time, mean } \pm \text { sd: mean, standard deviation, CBP: kardiyopulmoner } \\
\text { by-pass time, EF15: postoperative 15th day ejection fraction }\end{array}$ & \\
\hline
\end{tabular}


There was a significant difference between the groups in preoperative and postoperative 1st day nt-proBNP values $(\mathrm{p}<0.05)$. There was no significant difference between the 2 groups after nt-proBNP measurements on the postoperative 7 th day ( $p>0.05)$. A significant increase in ntproBNP values was observed in both groups until the 7 th postoperative day $(\mathrm{p}<0.001)$. It was observed that the median values of preoperative nt-proBNP measurements increased 2.99 times on the postoperative 1st day and 3.26 times on the postoperative 7 th day in the experimental group. In the control group, it was found that it increased 3.35 times on the postoperative 1st day and 5.50 times on the 7th day. Although this increase was statistically significant in both groups, it was observed that the increase in the control group was higher. Change values are shown in Table 4.

\begin{tabular}{|c|c|c|c|c|c|}
\hline & $\mathbf{P}$ & mean \pm sd & P0 & P1 & P7 \\
\hline \multirow{3}{*}{$\begin{array}{l}\text { Experimental } \\
\text { group }\end{array}$} & P0 & $1599.2 \pm 923.2$ & $\cdot$ & 0.002 & 0.000 \\
\hline & $\mathrm{P} 1$ & $4795.6 \pm 2274.1$ & 0.002 & · & 0.928 \\
\hline & P7 & $5215.9 \pm 3073.2$ & 0.000 & 0.928 & - \\
\hline Test results & - & $\mathrm{p}<0.001$ & - & - & - \\
\hline \multirow{3}{*}{$\begin{array}{l}\text { Control } \\
\text { group }\end{array}$} & P0 & $795.5 \pm 731.2$ & - & 0.005 & 0.000 \\
\hline & $\mathrm{P} 1$ & $2667.3 \pm 1078.8$ & 0.005 & $\cdot$ & 0.010 \\
\hline & P7 & $4370.1 \pm 1588$ & 0.000 & 0.010 & · \\
\hline Test & - & $\mathrm{p}<0.001$ & - & - & - \\
\hline
\end{tabular}

The mean EF was 33.5 in the experimental group and 38 in the control group. It was observed that postoperative EF values increased in both groups compared to preoperative data. The mean values of EF measurements measured on the postoperative 15th day were 39 in the experimental group and 40 in the control group. The increase in EF values was greater in the experimental group. It was observed that this increase was more significant in the experimental group $(\mathrm{P}=0.008)$. The data are shown in Table 5.

\begin{tabular}{|lcc|}
\hline Table 5. EF values in the experimental group and the control group & $\begin{array}{c}\text { Experimental group } \\
\text { median (25-75\%) }\end{array}$ & $\begin{array}{c}\text { Control group } \\
\text { median (25-75\%) }\end{array}$ \\
\hline EF 0 & 33.50 & 38 \\
EF 15 & 39 & 40 \\
p value & $\mathrm{P}=0.008$ & $\mathrm{P}=0.012$ \\
EF: Ejection fraction. & &
\end{tabular}

Mean CC time was $66.4 \pm 28.14$ minutes in the experimental group, while it was $64.9 \pm 18.6$ minutes in the control group. There was no statistically significant difference between the groups in terms of CC times $(\mathrm{p}>0.05)$.
While the average number of sick vessels was 4 in the experimental group, it was 4 in the control group. The median value of the number of anastomoses performed was calculated as 3 in the experimental group and 3.5 in the control group. There was no significant difference ( $\mathrm{p}>0.05)$.

Dopamine and dobutamine infusion was started in 5 patients who developed low cardiac output postoperatively in the experimental group and 8 patients in the control group. Despite the need for more inotropics in the control group, there was no significant difference between the groups as a result of the statistical analysis ( $p>0.05)$.

Intraaortic balloon pump support was provided to 2 patients in the experimental group and to 1 patient in the control group due to low cardiac output. There was no statistically significant difference between the groups in terms of the need for intraaortic balloons $(p>0.05)$.

\section{DISCUSSION}

Studies have shown that CABG provides improvement in long-term surveillance in patients with impaired ventricular function (13). Despite advanced surgical techniques, myocardial protection and postoperative care, the surgical risk is still high. It is known that surgical manipulation, global ischemia, reperfusion injury, hypothermia and CPB have damaging effects on myocardium (14).

No statistically significant difference was found between the groups in terms of age, comorbitidity, CPB time, CC time, number of patient vessels, number of anastomosis, extubation times, length of stay in intensive care and hospital stay. No significant difference was observed between the groups in preoperative EF values $(\mathrm{p}>0.05)$.

In this study, nt-proBNP levels, which are considered to be an indicator of left ventricular dysfunction, were examined perioperatively. The efficacy of the levosimendan treatment given in terms of protecting myocardial functions was investigated by making simultaneous EF measurements. Due to the damaging effects of CABG on the myocardium, an increase in postoperative nt-proBNP values is observed. It is known that postoperative high nt-proBNP values are associated with intraoperative and postoperative complications in patients undergoing CABG surgery (15). Similarly, in our study, an increase in nt-proBNP levels was found in the postoperative period. However, it was observed that the increase in mean nt-proBNP values in the experimental group was lower than the control group. After 24 hours, an average increase of 2.99 times in the experimental group and 3.35 times in the control group was noted in the nt-proBNP value. Similarly, the increase in the values 
measured on the 7th postoperative day was less in the experimental group (3.26 in the experimental group, 5.50 in the control group). Although this increase was statistically significant in both groups, it was observed that the increase in the control group was higher $(\mathrm{p}<0.001)$. In many studies evaluating the treatment of congestive heart failure with levosimendan, nt-proBNP was used as a neurohormonal marker and it was observed that the improvement in symptoms and the decrease in nt-proBNP levels were parallel to each other (16). Levosimendan, developed for the short-term treatment of acute exacerbations of heart failure, has been shown in many studies to be more effective than conventional inotropic treatment methods. It has been observed that the maximum benefit from treatment after levosimendan infusion takes 24-48 hours after infusion (17-18). CABG complications due to ischemia and reperfusion (such as low cardiac output) are most common in the first 48 hours postoperatively (19). Therefore, it is inevitable that the drug will be most beneficial in these patients during this period. As seen in our data analysis, similar to other studies, the change in nt-proBNP values increased less significantly in the experimental group than in the control group in the first 24 hours after the operation. In the experimental group, it was observed that the median values of preoperative nt-proBNP measurements increased 2.99 times on the postoperative 1st day and 3.26 times on the postoperative 7 th day. In the control group, it was found to increase 3.35 times on the postoperative 1 st day and 5.50 times on the 7 th day $(\mathrm{p}<0.001)$. Although this increase was statistically significant in both groups, it was observed that the increase in the control group was higher. This shows the cardioprotective activity of levosimendan.

It is accepted that CABG improves postoperative symptoms and survival in patients with LVD (20). Similar data were obtained in this study that we conducted. In both groups, it was found that there was an increase in EF values measured on the postoperative 15th day, statistically, the increase in the experimental group was found to be more significant $(p=0.002)$. The reason for this change in $\mathrm{EF}$ value in the experimental group was thought to be the result of the beneficial effect of levosimendan on the myocardium alone (such as global ischemia, reperfusion, hypothermia, CC. systemic inflammatory response), as well as its beneficial effect on ischemic myocardium and hyperne myocardial functions at the end of the first 2 weeks postoperatively. We found that there was a significant increase in postoperative EF values of patients with low EF in both groups.

Although levosimene has been shown to be effective in acute heart failure, its use in open heart surgery is still not standard, according to recent studies. Studies are needed to demonstrate the cardioprotective activity of levosimendan in subgroups of open heart surgery (21). We think that levosimendan treatment will significantly contribute to $\mathrm{CABG}$ in long-term surveillance but data analysis will be healthier with similar studies to be conducted in a larger patient group.

\section{CONCLUSION}

As a result of this study, it has been shown that levosimendan has a positive effect on myocardial protection and contractility in CAD with LVD when combined with CABG.

\section{ETHICAL DECLARATIONS}

Ethics Committee Approval: This prospective research was approved by the Ethics Committee of Eskişehir Osmangazi University Faculty of Medicine (Date: 10.11.2008, No: 2008/454).

Informed Consent: All patients participating in the study have signed the Informed Consent Form

Referee Evaluation Process: Externally peer-reviewed.

Conflict of Interest Statement: The authors have no conflicts of interest to declare.

Financial Disclosure: There is no person/organization that financially supports the study.

Author Contributions: The authors declared that they have all participated in the design, execution, and analysis of the paper, and that they have approved the final version.

\section{REFERENCES:}

1. Trachiotis MD, Weintraub MD, Johnston MD, Jones MD, et al. Coranary artery bypass grafting in patients with advanced left ventriculer dysfunction. Ann Thorac Surg 1998; 66: 1632-9.

2. Kirklin JK. Prospects for understanding and eliminating the deleterious effects of cardiopulmonary bypass. Ann Thorac Surg 1991; 51: 529-31.

3. Temporelli PL, Scapellato F, Corra U, et al. Perioperative and Postoperative Predictors Of Outcome in Patient in low Ejection Fraction Early After Coronary Artery By Pass Grefting. EAPC 2008; 15: 441-7.

4. Allman K.C. Shaw LJ, Hachamovitch. Myocardial viability testing and impact of revascularization on prognosis in patients with coronary arter disease and left ventrikular dysfonction: A meta analysis. J Am Coll Card. 2002; 39: 1151-8.

5. Anderson JL, Marshal HW, Bray BE. A randomized trial of intracoronary streptokinase in the treatment of acute myocardial infarction. N. Engl. J. Med. 1983 308: 1312-8.

6. Bonow RO. The hibernating myocardium: Implications for management of congestive heart failure. AJC 1995; 75: 17-25.

7. Packer M, Leier CV. Survival in congestive heart failure during treatment with drugs with positive inotropic actions. Circulation 1987; 75: 55-63.

8. Haikala H, Linden IB. Mechanisms of action of calciumsensitizing drugs. JBF 1998; 60: 10-9. 
9. Sorsa T, Heikkinen S, Abbot MB, Abusamhadneh E, Laakso T, Tilgman C. Binding of levosimendan, a calcium sensitizer, to cardiac troponin C. JBC 2001; 276: 9337-43.

10. Kaheinen P, Polleselo P, Levijoki J, Haikala H. Levosimendan increases diastolic coronary flow in isolated guinea-pig heart by opening ATP-sensitive potassium channels. JCP 2001; 37: 367-74.

11. Korkmaz H, Yilmaz M. “The effects of levosimendan use on highsensitivity C-reactive protein in patients with decompensated heart failure", AMS 2019; 4: 174-9.

12. Kivikko M, Antila S, Eha J, Lehtonen L, Pantikainen PJ. Pharmacokinetics of levosimendan and its metabolites during and after a 24-hour continuous infusion in patients with severe heart failure. JCPT 2002; 40: 465-71.

13. Carr JA, Haithcokk BE, Paone G. Long term out come after coronary artery by pass garfting in patients with severe left ventrikular dysfonction: Ann Thorac Surg 2002; 74: 1531-6.

14.Allman K.C. Shaw LJ, Hachamovitch D. Myocardial viability testing and impact of revascularization on prognosis in patients with coronary arter disease and left ventrikular dysfonction: A meta analysis. J Am Coll Card. 2002; 39: 1151-8.

15.Lu YF, Qi HW, Tang CZ, Wu MY, Wang Y, Zhao FY. Change of $\mathrm{N}$-terminal pro-brain natriuretic peptide and big endothelin in patients undergoing coronary artery bypass grafting. Zhongguo Wei Zhong Bing Ji Jiu Yi Xue 2007; 19: 667-70.

16. Parissis J.T, Adamopoulos S, Farmakis D, at al. G. Effect of serial levosimendan infusions on left ventricular performance and plasma biomarkers of myocardial injury and neurohormonal and immune activation in patients with advanced heart failure. Heart 2006; 92: 1768-72.

17. Kyrzopoulos S, Adamapoulos S, Parissis J.T, at al. Levosimendan reduces plasma B-type natriuretic peptide and interleukin 6 and improves central hemodynamics in severe heart failure patients. International JC 2004; 99: 409-13.

18. Celik T, İyisoy A, Yüksel UC, Kardeşoğlu E. The prolonged lowering effect of levosimendan on brain natriuretic peptide levels in patients with decompansated heart failure: Clinical implications. İJC 2008; 128: 97-9.

19. Cheshire C, Bhagra CJ, Bhagra SK. "A review of the management of patients with advanced heart failure in the intensive care unit". Ann Transl Med 2020; 8: 828-42.

20.J.Skorpil, Brat R, Docekal B, Motyk O. Myocardial revascularisation in patients with severe left ventricular dysfunction. Early and midterm results. Biomed Papers 2004; 148: 55-8.

21.Santillo E, Migale M, Massini C, Incalzi RA. Levosimendan for Perioperative Cardioprotection: Myth or Reality? CCR 2018; 14 142-52. 